\title{
Immune and hormonal activity in adults suffering from depression
}

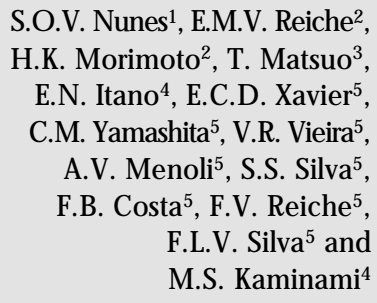

\author{
Departamentos de ${ }^{1}$ Clínica Médica and 2 Patologia Aplicada, Legislação e Deontologia, \\ Centro de Ciências da Saúde, U niversidade Estadual de Londrina, Londrina, PR, Brasil \\ ${ }^{3}$ Departamento de Matemática Aplicada, Centro de Ciências Exatas, \\ Universidade Estadual de Londrina, Londrina, PR, Brasil \\ ${ }^{4}$ Departamento de Ciências Patológicas, Centro de Ciências Biológicas, \\ Universidade Estadual de Londrina, Londrina, PR, Brasil \\ ${ }^{5}$ Curso de Medicina, Centro de Ciências da Saúde, \\ Universidade Estadual de Londrina, Londrina, PR, Brasil
}

\section{Correspondence \\ E.M.V. Reiche \\ Grupo de Estudos em \\ Psiconeuroimunologia \\ Departamento de Patologia Aplicada, \\ Legislação e Deontologia, CCS, UEL \\ Av. Robert Koch, 60 \\ 86038-440 Londrina, PR \\ Brasil \\ Fax: + 55-43-371-2323 \\ E-mail: reiche@ sercomtel.com.br \\ Research supported by Kellogg Foundation, PIBIC/CN Pq, IC/CPG/ \\ UEL, Diagnostic Products Corporation (DPC-M edlab), and Hospital \\ Universitário Regional Norte do \\ Paraná.}

Received August 7, 2001

Accepted March 11, 2002

\section{Abstract}

An association between depression and altered immune and hormonal systems has been suggested by the results of many studies. In the present study we carried out immune and hormonal measurements in 40 non-medicated, ambulatory adult patients with depression determined by CID- 10 criteria and compared with 34 healthy nondepressed subjects. The severity of the condition was determined with the Hamilton Depression Rating Scale. Of 40 depressed patients, 31 had very severe and 9 severe or moderate depression, 29 (72.5\%) were females and $11(27.5 \%)$ were males (2.6:1 ratio). The results revealed a significant reduction of albumin and elevation of $\alpha-1, \alpha-2$ and $\beta-$ globulins, and soluble IL-2 receptor in patients with depression compared to the values obtained for nondepressed subjects $(\mathrm{P}<0.05)$. The decrease lymphocyte proliferation in response to a mitogen was significantly lower in severely or moderately depressed patients when compared to control $(\mathrm{P}<0.05)$. These data confirm the immunological disturbance of acute phase proteins and cellular immune response in patients with depression. Other results may be explained by a variety of interacting factors such as number of patients, age, sex, and the nature, severity and/or duration of depression. Thus, the data obtained should be interpreted with caution and the precise clinical relevance of these findings requires further investigation.

\section{Introduction}

Many reports have considered a possible association between depressive disorders and immune and hormonal alterations, although the results obtained have not been consistent. The interactions between the central nervous system and the immune system in depression have a biological explanation supported by the monoamine hypothesis (1), dysregulation of hypothalamic-pituitary-
Key words

- Depression

- Immunity

- Psychoneuroimmunology

- Cytokines

- Acute phase proteins 
and the progression of immunodeficiency virus (HIV) infection (7). At the cellular level, some investigators have reported reduced mitogen-stimulated lymphocyte proliferation (8-10) although others have not (11-13). An increase in total white cell number and abnormality in differential white blood cell count with increased percentage of neutrophils and decreased lymphocytes have also been reported (4). However, most of the cell enumeration studies on depressed patients have yielded an unchanged number of white blood cells, neutrophils, lymphocytes, total T-cells or T cell subsets (14). Impairment of natural killer cell activity has been reported by several investigators $(7,15)$.

At the subcellular level, it has been reported that serum and plasma concentrations of immunoglobulins (IgA, IgM), C3 and C4 complement and acute phase proteins are changed in depressed patients $(4,16,17)$. Positive acute phase proteins such as the $\alpha-1$ acid glycoprotein, $\alpha-2$ globulins, C-reactive protein and haptoglobin are increased in depression, while negative acute phase proteins, such as albumin and transferrin, are decreased (18).

The assessment of the capacity of peripheral blood mononuclear cells of depressed patients to produce cytokines has also yielded controversial results (19). An increase in plasma concentration and in vitro production of IL-1 13 , plasma concentration of soluble IL-6 receptor, soluble IL-2 receptor and transferrin receptor were significantly higher in depressed patients than in healthy controls (20). A significant reduction in IL-1 B, IL-2 and IL-3-like activity was observed in untreated depressed patients when compared to controls and the IL- $1 ß$ and IL-3-like activity synthesis was significantly increased after drug treatment (14). Elevations in the concentrations of cytokines IL-1, interferon alpha (IFN- $\alpha$ ) and tumor necrosis factor (TNF) and reduction in IL-2 have been reported in depressed patients (4). Increased serum levels of pro-inflammatory cytokine
IL-1 and of IL- 6 have also been reported (21).

The hormonal abnormalities described in depression are secretion of corticotrophinreleasing factor and a neurally mediated hyperresponsivity of the adrenal gland to adrenocorticotropic hormone (ACTH) (22). There is an increased number of ACTH secretory episodes combined with an increased magnitude of cortisol-secretory episodes. Depending on the severity of depression and age, $20-50 \%$ of patients are defined as dexamethasone nonsuppressors. The corticotrophin-releasing factor system in association with altered sympathetic activity may be changed in depression, resulting in altered ACTH-cortisol ratios (23). Conflicting results about other hormones such as basal prolactin and thyroid hormone have been reported in depression (22).

The present study was undertaken to evaluate the levels of immune and hormonal components in adult ambulatory patients with depression in comparison with nondepressed subjects.

\section{Subjects and Methods}

\section{Subjects}

The study was conducted on 40 nonmedicated ambulatory adults with depressive episodes and 34 healthy nondepressed volunteers (control group). All subjects, patients and controls, were submitted to clinical evaluation according to CID-10 criteria (24) and the severity of depression was determined using the Hamilton Depression Rating Scale (25). The depressed patients were divided into two groups: 31 patients with very severe depression, with Hamilton Depression Scale scores higher than 23, and 9 patients with severe or moderate depression with Hamilton Depression Scale scores ranging from 19 to 22 for severe depression and from 14 to 18 for moderate depression. The control group presented scale scores of 
7 or less. The depressed and nondepressed subjects were seen at the Ambulatório de Clínica Médica, Hospital de Clínicas, Universidade Estadual de Londrina (UEL), Londrina, PR, Brazil, during the period from July 1998 to March 2000. Subjects younger than 18 years and older than 60 years were excluded from both groups. All subjects were required to be in good health, defined as the absence of chronic diseases which affect the immune system, HIV, and an acute or inflammatory response, for at least 2 weeks before the study and not to be taking medications with known effects on the immune system. Subjects taking recreational drugs and with a recent history of shock, malnutrition, irradiation, fever or cancer treatment were also excluded. The research was approved by the Ethics Research Committee of the UEL and written informed consent was obtained from all depressed and nondepressed subjects participating in the study after the procedures were fully explained.

\section{Immunological evaluation}

Immune determinations including total white blood cell count, differential counts and serum protein fractions were performed using standard procedures. Serum immunoglobulins (IgG, IgA, IgM), C3 and C4 complement, and C-reactive protein were determined by the immunonephelometric method (Dade Behring, Marburg, Germany), and plasma concentrations of IL-1ß, IL-6, TNF$\alpha$ and the soluble IL-2 receptor were determined by an automated chemoluminescent immunoenzymatic method (Immulite ${ }^{\circledR}$, Diagnostic Products Co., Los Angeles, CA, USA). The lymphocyte response to phytohemagglutinin stimulation was determined by standard methods (26).

\section{Hormonal evaluation}

The hormonal determinations included triiodothyronine (T3), thyroxine (T4), thy- rotrophin (TSH), prolactin (PRL), cortisol (blood samples were collected at 8:00 am), and the dexamethasone suppression test (DST). An oral dose of $1 \mathrm{mg}$ dexamethasone was given at 11:00 pm to patients and control subjects. The next day, serum cortisol levels were assayed in blood samples collected at 4:00 and 11:00 pm. All of these hormonal evaluations were made by radioimmunoassay using commercial products. The result of the DST was considered to be normal when the cortisol values were less than $5 \mu \mathrm{g} / \mathrm{dl}$ from 8 to $24 \mathrm{~h}$ after an oral dose of $1 \mathrm{mg}$ dexamethasone given at 11:00 pm (27). The serum levels of dehydroepiandrosterone sulfate (S-DHEA), ACTH, and growth hormone were assayed by an automated chemoluminescent immunoenzymatic method (Immulite ${ }^{\mathbb{R}}$ ).

Whenever possible, blood samples from patients and controls were collected in the morning between 8:00 and 10:00 am and processed together on the same day to control for day-to-day variation in the assay. The blood samples were identified by a sequential number with no difference between groups (patients and controls). All assays were performed using standard procedures according to manufacturer instructions.

\section{Statistical analysis}

Data were analyzed statistically by the Ftest for analysis of variance (ANOVA), Kruskal-Wallis test, and chi-square test. When the results showed significant differences, the Tukey test was used to compare the means obtained for the groups assayed. The results are reported as means \pm standard deviation (SD). A difference between the two groups was considered to be statistically significant when $P<0.05$. All levels of significance were two-tailed.

\section{Results}

The characteristics of adult patients with 
very severe, severe or moderate depression and of nondepressed (control group) subjects were as follows. Of the 40 depressed patients, $29(72.5 \%)$ were females and 11 $(27.5 \%)$ were males. The female to male ratio was $2.6: 1 ; 31$ patients (8 males and 23 females) aged $18-58$ years $(35.90 \pm 11.20)$ presented very severe depression with mean Hamilton Depression Scale scores ranging from 23 to $50(32.84 \pm 6.75)$. The diagnosis of severe or moderate depression was made in 9 patients ( 3 males and 6 females) aged $19-57$ years $(36.44 \pm 14.23)$ with Hamilton Depression Scale scores ranging from 18 to $22(20.44 \pm 1.59)$. Among the 34 nondepressed subjects (9 males and 25 females) aged 18-56 years $(34.94 \pm 11.78)$, the mean Hamilton Depression Scale score ranged from 0 to $7(2.23 \pm 2.24)$. The severity of depression among the groups was statistically evaluated by the Kruskal-Wallis test. The mean values, $2.23 \pm 2.24,20.44 \pm 1.59$ and $32.84 \pm 6.75$, were significantly different when compared by the Tukey test $(\mathrm{P}<0.05)$.

The results of the hematologic determinations on peripheral blood for leukocytes, neutrophils, typical lymphocytes, monocytes,

Table 1. Biochemical analysis of the plasma of adults with very severe, severe or moderate depression and control nondepressed subjects.

\begin{tabular}{lrcr}
\hline Parameter (mean \pm SD) & $\begin{array}{c}\text { Control } \\
\text { group } \\
(\mathrm{N}=34)\end{array}$ & $\begin{array}{c}\text { Severely or moderately } \\
\text { depressed patients } \\
(\mathrm{N}=9)\end{array}$ & $\begin{array}{c}\text { Very severely } \\
\text { depressed patients } \\
(\mathrm{N}=31)\end{array}$ \\
\hline Mucoprotein (mg/dl) & $0.86 \pm 0.36$ & $0.92 \pm 0.20$ & $0.99 \pm 0.37$ \\
Total protein (g/dl) & $7.10 \pm 0.78$ & $7.25 \pm 0.69$ & $7.50 \pm 0.76$ \\
Albumin (\%) & $53.0 \pm 7.76$ & $47.40 \pm 4.52$ & $46.76 \pm 5.93^{*}$ \\
Albumin (g/dl) & $3.79 \pm 0.60$ & $3.47 \pm 0.35$ & $3.43 \pm 0.53$ \\
$\alpha-1$ Globulin (\%) & $2.50 \pm 0.92$ & $3.05 \pm 0.74$ & $3.38 \pm 1.09^{*}$ \\
$\alpha-1$ Globulin (g/dl) & $0.18 \pm 0.06$ & $0.22 \pm 0.04$ & $0.24 \pm 0.07^{*}$ \\
$\alpha-2$ Globulin (\%) & $8.67 \pm 1.94$ & $9.64 \pm 2.12$ & $10.07 \pm 1.63^{*}$ \\
$\alpha-2$ Globulin (g/dl) & $0.62 \pm 0.16$ & $0.71 \pm 0.13$ & $0.75 \pm 0.15^{*}$ \\
B-Globulin (\%) & $15.17 \pm 2.65$ & $14.55 \pm 2.49$ & $17.16 \pm 2.86^{*}$ \\
B-Globulin (g/dl) & $1.09 \pm 0.21$ & $1.08 \pm 0.21$ & $1.28 \pm 0.26^{*}$ \\
$\gamma$-Globulin (\%) & $20.32 \pm 4.94$ & $24.91 \pm 5.22$ & $22.43 \pm 3.92$ \\
$\gamma$-Globulin (g/dl) & $1.46 \pm 0.41$ & $1.84 \pm 0.43$ & $1.68 \pm 0.38$ \\
\hline
\end{tabular}

Data are reported as means \pm SD.

$* \mathrm{P}<0.05$ compared to control group (ANOVA test, Tukey test). eosinophils and basophils for the patients with very severe, severe or moderate depression did not differ significantly from the values obtained for the control group.

Table 1 shows the blood analyses. The albumin fraction percentage was lower in the very severely depressed patients when compared with the control group $(\mathrm{P}<0.05)$. The absolute and relative serum levels of $\alpha-1, \alpha-2$, and $\beta$-globulins were significantly higher in the very severely depressed patients than in the control group $(\mathrm{P}<0.05)$. The results of other biochemical parameters assayed such as mucoprotein, total serum proteins and $\gamma$-globulin did not differ significantly among groups.

Of the immune parameters evaluated, serum IgG, IgM, IgA, C-reactive protein, C3, C4, cytokines IL- $1 \beta$, and TNF- $\alpha$ levels did not differ significantly between patients and controls. Serum IL-6 levels were lower in the severely or moderately depressed patients when compared to the controls $(\mathrm{P}<0.05)$. Serum soluble IL-2 receptor levels were lower in the severely or moderately depressed patients when compared with very severely depressed patients and the control group $(\mathrm{P}<0.05)$.

The lymphocyte stimulation response to phytohemagglutinin, expressed by the stimulation index, in the very severely, severely or moderately depressed patients and control group was 1.642, 1.014, and 2.129, respectively. Statistical analysis showed that the stimulation index was lower in the severely or moderately depressed patients when compared to the control group $(\mathrm{P}<0.05)$.

A subject was considered to be a nonsuppressor if the serum cortisol result obtained from a sample collected at 4:00 or 11:00 pm was similar to or higher than $5 \mu \mathrm{g} / \mathrm{dl}$. The results of the DST revealed that the rate of nonsuppressors did not differ significantly between depressed patients and controls (21.1 and $36.7 \%$, respectively). The serum levels of T3, T4, TSH, PRL, cortisol at 8:00 am, cortisol after DST (4:00 and 11:00 pm), 
S-DHEA, ACTH, and growth hormone did not differ between patients and controls.

\section{Discussion}

The study evaluated the immunological and hormonal parameters of a group of very severely, severely or moderately depressed patients compared to nondepressed subjects. The female to male ratio of 2.6:1 was in keeping with the gender distribution found among patients with depression (28). Peripheral blood cell counts showed no differences in the number of white blood cells, neutrophils, lymphocytes or monocytes, in accordance with most of the cell enumeration studies in depressive disorders reporting an unaltered number of white blood cells, neutrophils, lymphocytes, total T-cells as well as T cell subsets, helper suppressor cell ratio, and $\mathrm{B}$ cells $(14,29,30)$.

The significant reduction observed in serum albumin levels among very severely depressed patients, and a significant elevation in the serum levels of positive acute phase proteins among the very severely depressed patients when compared with the control subjects are consistent with most published reports $(4,18,19,29,31)$. The findings that stressors may be able to activate the release of proinflammatory cytokines and an acute-phase response in the absence of an immune challenge further support the notion that the immune system may be recruited to participate in the behavioral response to stress, and therefore may contribute to the biochemical and molecular biological changes that characterize depression (21). The acute phase proteins are mediated by the pro-inflammatory cytokines, mainly by IL1, IL-6 and TNF which in depressed patients seem to be correlated with the severity of the disease and the hyperactivity of the hypothalamic-pituitary-adrenocortical axis. Research on cytokine regulation in depression has been controversial. Some researchers have reported a reduced production of IL-1ß (14) and IL-2 $(4,14)$ by peripheral blood mononuclear cells in patients with major depression before treatment, reflecting an adaptive feedback mechanism for the prevention of pituitary ACTH hypersecretion. However, others have reported that depression may be associated with higher serum concentrations of IL-1, IFN- $\alpha$ and TNF (4), IL-1ß, IL-6, and IFN- $\gamma$ (32). An increase in plasma IL-6, soluble IL-6 receptor and soluble IL-2 receptor concentrations among depressed patients was reported in a study in which the authors stated that the increased production of IL- 6 may represent a contributing factor to the various immune disorders encountered in major depression and perhaps to the pathophysiology or pathogenesis of this illness. However, these results were obtained among DST nonsuppressor depressed patients (20). The present study evaluated all depressed patients, DST suppressor and DST nonsuppressor. This difference could contribute to the disagreement of the results obtained. Another difference that could explain the results is that this study evaluated only ambulatory depressed patients, and not hospitalized depressed patients.

Mitogen-induced lymphocyte stimulation in the depressed patients assayed here confirmed the impaired cellular immune response, as revealed by the decreased lymphocyte proliferation in response to phytohemagglutinin, in agreement with previous studies $(10,13,27)$.

The results obtained by T3, T4 and TSH evaluation were not significantly different among groups. The majority of depressed patients appeared to be euthyroid and changes in these measurements have been reported in a substantial minority of depressed patients. The results concerning basal PRL levels reported for depressed patients are conflicting. Basal PRL has been found to be low, normal and elevated and the underlying cause of the disturbances in PRL regulation in affective disorders is still unclear (22). As regards basal plasma cortisol and cortisol levels after 
DST, the difference was not significant among the groups assayed. Only a $21.1 \%$ rate of nonsuppression was demonstrated among depressed patients evaluated in this study. According to previous studies, an impaired feedback inhibition resulting in an abnormal DST is registered in approximately $45 \%$ of patients with depression (22). However, the results obtained among the controls (36.7\% DST nonsuppressor) are in agreement with reports about the hypothalamicpituitary adrenocortical alteration in healthy controls at risk for depression. In healthy subjects who had never suffered from minor or major psychiatric illness, but whose family members were highly loaded with depression, several neurobiological signs of depression were found to be present, including the response to the DST-CRH test (23). These findings could suggest the usefulness of the DST results as a biological marker in those individuals from a high-risk population who present abnormal DST results. These subjects could be at higher risk for developing depression than those who have normal DST results.

Depression is by no means a homogeneous disorder, but is in fact a complex phenomenon which has many subtypes, and probably more than one etiology (32). A variety of interacting factors may have con- tributed to the results obtained in the present study such as patient age, dexamethasone suppressor or nonsuppressor status, whether the patients are experiencing acute depression or are in remission, the severity and/or duration of depression and whether patients are drug-free (and for how long), and the presence or absence of any kind of therapy $(27,33,34)$. The difficulty to control some variables which could affect the parameters evaluated, such as tobacco use, alcohol and caffeine consumption, activity and exercise levels, may have affected the results $(13,35$, 36). The fact that the control subjects were volunteers and self-selected shows that this sample does not represent the general population.

The results obtained added to other previous reports about the evidence of an association of immune abnormalities, both activation and depression, with depressive illness. The immune system activation would be characterized by the increased acute phase proteins and the immune system depression by the reduced mitogen-stimulated lymphocyte proliferation observed in the depressed patients evaluated. However, the conclusions reached in light of these results require a cautious interpretation and the precise clinical relevance of these findings requires further investigation.

\section{References}

1. Baldessari R (1975). The basis for amine hypotheses in affective disorders. Archives of General Psychiatry, 32: 10871093.

2. Bateman A, Singh A, Kral T \& Solomon S (1989). The immune-hypothalamic-pituitary-adrenal axis. Endocrine Reviews, 10: 92-102.

3. Smith RS (1991). The macrophage theory of depression. Medical Hypothesis, 35: 298-306.

4. Leonard BE \& Song C (1996). Stress and the immune system in the etiology of anxiety and depression. Pharmacology, Biochemistry and Behavior, 54: 299-303.
5. Zorrilla EP, McKay JR, Luborsky L \& Schmidt K (1996). Relation of stressors and depressive symptoms to clinical progression of viral illness. American J ournal of Psychiatry, 153: 626-635.

6. Spielgel D (1996). Cancer and depression. British J ournal of Psychiatry, 168: 109116.

7. Leserman J, Petitto J M, Golden RN, Gaynes BN, Gu H, Perkins DO, Silva SG, Folds J D \& Evans DL (2000). Impact of stressful life events, depression, social support, coping, and cortisol on progression to AIDS. American J ournal of Psychiatry, 157: 1221-1228.
8. Kronfol Z, Silva J, Greden J, Dembinsk S, Gardner R \& Carroll BJ (1983). Lymphocyte function in melancholia. Life Sciences, 33: 241-247.

9. Kronfol Z, House J D, Silva J , Greden J \& Carroll BJ (1986). Depression, urinary free cortisol excretion and lymphocyte function. British J ournal of Psychiatry, 148: 70-73.

10. Schleifer SJ, Keller SE, Meyerson AT, Raskin MJ, Davis KL \& Stein M (1984). Lymphocyte function in major depressive disorder. Archives of General Psychiatry, 41: 484-486.

11. Schleifer SJ, Keller SE, Siris SG, Davis KL 
\& Stein M (1985). Depression and immunity. Lymphocyte function in ambulatory depressed patients, hospitalized schizophrenic patients, and patients hospitalized for herniorrhaphy. Archives of General Psychiatry, 42: 129-133.

12. Schleifer SJ , Keller SE, Bond RN, Cohen J $\&$ Stein M (1989). Major depressive disorder and immunity: role of age, sex, severity, and hospitalization. Archives of General Psychiatry, 46: 81-87.

13. Schleifer SJ, Keller SE \& Bartlett JA (1999). Depression and immunity: clinical factors and therapeutic course. Psychiatry Research, 85: 63-69.

14. Weizman R, Laor N, Podliszewski E, Notti I, Djaldetti M \& Bessler H (1994). Cytokine production in major depressed patients before and after clomipramine treatment. Biological Psychiatry, 35: 42-47.

15. Irwin $M$, Daniels $M$, Bloom $E$, Smith $T \&$ Weiner H (1987). Life events, depressive symptoms and immune function. American J ournal of Psychiatry, 144: 437-441.

16. Kronfol Z, Nair M, Goodson J, Goel K, Haskett R \& Schwartz S (1989). Natural killer cell activity in depressive illness: preliminary report. Biological Psychiatry, 26: 753-756.

17. Maes M, Scharpe S, van Grottel I, Uyttenbroeck W, Cooreman W, Cosyns P \& Suy E (1992). Higher alpha 1-antitrypsin, haptoglobin, ceruloplasmin and lower retinol binding protein plasma levels during depression: Further evidence for the existence of an acute phase response. J ournal of Affective Disorders, 24: 183-192.

18. Hornig M, Goodman DBP, Kamoun M \& Amsterdam J D (1998). Positive and negative acute phase proteins in affective subtypes. J ournal of Affective Disorders, 49: 9-18.

19. Kronfol Z\& Remick DG (2000). Cytokines and the brain: implications for clinical psychiatry. American J ournal of Psychiatry, 157: 683-694.
20. Maes M, Meltzer HY, Bosmans E, Bergmans R, Vandoolaeghe E, Ranjan R \& Desnyder R (1995). Increased plasma concentrations of interleukin- 6 , soluble interleukin-6, soluble interleukin-2 and transferrin receptor in major depression. J ournal of Affective Disorders, 34: 301-309.

21. Miller A, Pearce B \& Pariante C (2000). Immune system and central nervous system interaction. In: Sadock B \& Sadock V (Editors), Comprehensive Textbook of Psychiatry. Williams A \& Wilkins, Baltimore, MD, USA, 113-132.

22. DeM oranville BM \& J ackson IMD (1996). Psychoneuroendocrinology. In: Fogel BS, Schiffer RB \& Rao SM (Editors), Neuropsychiatry. Williams A \& Wilkins, Baltimore, MD, USA, 173-192.

23. Holsboer $F \&$ Barden N (1996). Antidepressants and hypothalamic-pituitaryadrenocortical regulation. Endocrine Reviews, 17: 187-205.

24. World Health Organization (1998). Classificação de Transtornos Mentais e de Comportamento da CID-10. Critérios Diagnósticos para Pesquisa. Artes Médicas, Porto Alegre, RS, Brazil.

25. Blacker D (2000). Psychiatry Rating Scales. In: Sadock B \& Sadock V (Editors), Kaplan and Sadock's Comprehensive Textbook of Psychiatry. 7th edn. Lippincott Williams \& Wilkins, Philadelphia, PA, USA, 755-783.

26. Mazzarin AP, Ono MA, Tonon J, Koga LV \& Itano EN (1995). Efeito de Rs1 e Rs2 de soros de pacientes com hanseníase na cultura de linfócitos. Revista Brasileira de Análises Clínicas, 27: 43-46.

27. Thase ME (2000). Mood disorders: Neurobiology. In: Sadock B \& Sadock V (Editors), Kaplan and Sadock's Comprehensive Textbook of Psychiatry. 7th edn. Lippincott Williams \& Wilkins, Philadelphia, PA, USA, 1322-1323.

28. Schleifer SJ, Keller SE, Bartlett JA, Eckholdt HM \& Delaney BR (1996). Im- munity in young adults with major depressive disorder. American J oumal of Psychiatry, 153: 477-481.

29. Kronfol Z \& House JD (1989). Lymphocyte mitogenesis, immunoglobulin and complement levels in depressed patients and normal controls. Acta Psychiatrica Scandinavica, 80: 142-147.

30. Stein M, Miller AH \& Trestman RL (1991). Depression, the immune system, and health and illness. Findings in search of a meaning. Archives of General Psychiatry, 48: 171-177.

31. Sluzewska A, Sobieska M \& Rybakowski J K (1997). Changes in acute-phase proteins during lithium potentiation of antidepressants in refractory depression. Neuropsychobiology, 35: 123-127.

32. Connor T \& Leonard B (1998). Depression, stress and immunological activation: the role of cytokines in depression disorders. Life Sciences, 62: 583-606.

33. Ader R, Madden $\mathrm{K}$, Felten DL, Bellinger DL \& Schiffer RB (1996). Psychoneuroimmunology: interactions between the brain and the immune system. In: Fogel BS, Schiffer RB \& Rao SM (Editors), Neuropsychiatry. Williams $A \&$ Wilkins, Baltimore, MD, USA, 193-221.

34. Pariante $C M$, Carpiniello $B$, Orru MG, Sitzia R, Piras A, Farci AM, Del-Giacci GS, Piludu G \& Miller AH (1997). Chronic caregiving stress alters peripheral blood immune parameters: the role of age and severity of stress. Psychotherapy and Psychosomatics, 66: 199-207.

35. J ung W \& Irwin M (1999). Reduction of natural killer cytotoxic activity in major depression: interaction between depression and cigarette smoking. Psychosomatic Medicine, 61: 263-270.

36. Schleifer SJ, Keller SE, Camerino M, Thornton J C \& Stein M (1983). Suppression of lymphocyte stimulation following bereavement. J ournal of the American Medical Association, 250: 372-377. 